\title{
Burden, Stress and Coping Strategies of Intellectually Disabled Children
}

\author{
Dr. Thiyam Kiran Singh ${ }^{1}$, Priyanka Panday ${ }^{2}$
}

\section{ABSTRACT:}

Aim of this research is to find out the burden, stress and coping strategies of intellectually disabled children on parents. In this study two groups one is male and other is female were selected. A total of 51 samples were collected out of which 26 are Male group and 25 are Female group. Data were collected from SMS Psychiatry Centre, Jaipur. Tools used for data collection are caregiver burden questionnaire developed by Kaur and Arora (2010), Perceived stress scale by Cohen (1983), Coping inventory by Carver and Scheier (1989). In this study 2x2 factorial design was adopted for analyzing data. The Result of this study showed there is significant difference between male and female on burden indicating higher burden on male parents. There is significant difference of stress between male and female parents indicating higher perceived stress on female parents. There is significant difference between male and female parents on coping indicating male parents are having good coping skills in comparison to female parents. The study concluded that male parents are getting more burden, female parents gets more stress and when concerned about coping male parents are good in coping strategies than female parents.

Keywords: Burden, Stress, Coping, Intellectual disable

\section{Concept of Mental Retardation:}

Mental retardation is perceived differently by different people, ranging from "burdens to the family to productive members of the society ". Mental retardation is a subnormal state of intelligence. It is not an illness but a condition of poor development of the brain. Children who have this condition are called dull or mentally retarded. Though mental retardation is a condition, like visual or auditory disabilities, it is less understood or misunderstood because of its inconspicuous nature.

A mentally retarded person most often, looks normal without physical deformities and therefore people have difficulties in understanding why he or she acts and behaves differently from others.

${ }^{1}$ Associate Professor (Clinical Psychology) Department of Psychiatry, Government Medical College and Hospital, Chandigarh.

${ }^{2}$ M.Phil Research Scholar, Amity University Rajasthan, Jaipur- 302002, Rajasthan.

(C) 2015 I T Singh, P Panday; licensee IJIP. This is an Open Access Research distributed under the terms of the Creative Commons Attribution License (http://creativecommons.org/licenses/by/2.0), which permits unrestricted use, distribution, and reproduction in any Medium, provided the original work is properly cited. 


\section{Classification of Mental Retardation:}

The two major classificatory systems ICD-10 and DSM-IV have classified mental retardation into four degrees of severity as shown in the table below-

\begin{tabular}{|c|c|c|c|c|}
\hline \multirow{2}{*}{$\begin{array}{ll}\text { Level } & \text { of } \\
\text { Retardation }\end{array}$} & \multicolumn{2}{|l|}{ I.Q. Level } & \multirow[t]{2}{*}{ Mental Age } & \multirow{2}{*}{$\begin{array}{l}\text { Proportation } \\
\text { of MR group } \\
\text { percent }\end{array}$} \\
\hline & DSM-IV & ICD-10 & & \\
\hline $\begin{array}{l}\text { Mild Mental } \\
\text { Retardation }\end{array}$ & $\begin{array}{ll}50-55 & \text { to } \\
\text { approx. } 70 . & \end{array}$ & $50-70$ & 9-12 Yrs & $85 \%$ \\
\hline $\begin{array}{l}\text { Moderate Mental } \\
\text { Retardation }\end{array}$ & $35-40$ to $50-55$ & $35-49$ & 6-9 Yrs & $10 \%$ \\
\hline $\begin{array}{l}\text { Severe Mental } \\
\text { Retardation }\end{array}$ & $20-25$ to $35-40$ & 20 to 34 & 3-6 Yrs & $3 \%$ to $4 \%$ \\
\hline $\begin{array}{l}\text { Profound Mental } \\
\text { Retardation }\end{array}$ & below 20 or 25 & less than 20 & Less than 3 Yrs & $\begin{array}{l}\text { Approx. } 1 \% \text { to } \\
2 \%\end{array}$ \\
\hline
\end{tabular}

\section{DEFINITION OF DISABILITY}

1. Jablensky et al. (1980): Disability may be defined as disturbances in performance of social roles that would normally be expected of an individual in the habitual milieu, arising in association with diagnosable mental disorder.

2. According to American association of Mental deficiency (1983), "Mental retardation can be defined as a significantly sub average general intellectual functioning, resulting or associated with concurrent impairment in adaptive behavior and is manifested during the developmental period"

3. World Health Organization (1980). "An impairment is an anatomical defect, or absence or loss of a specific psychological or physiological function that can arise from a disease or from an intrinsic pathological state".

- A disability is a restriction in the ability to perform a task or activity within the range normally expected or someone of the same age or level of maturity.

4. According to Persons with Disabilities (Equal Opportunities, Protection of Right and Full Participation) Act, 1995

a. "disability" means -
i. Blindness;
ii. Low vision;
iii. Leprosy-cured;
iv. Hearing impairment;
v. Locomotors disability;
vi. Mental retardation;
vii. Mental illness; 
"Person with disability" means a person suffering from not less than forty per cent of any disability as certified by a medical authority (Singh, 2008).

Mental Retardation is a highly prevalent and highly disabling condition. It is generally considered that two percent of the Indian population constitutes persons with mental retardation. In India prevalence of mental retardation varies from 0.22 percent (ICMR, 1983) to 32.7 per thousand populations.

\section{Methodology:}

\section{Objectives of Study:}

1. To assess the level of burden of intellectually disabled children on parents.

2. To assess the level of stress of intellectually disabled children on parents.

3. To assess the coping of intellectually disabled children on parents.

\section{Research Design:}

This research was adopted 2x2 factorial design with 2 types of gender (male and female) and 2 types of education (graduation and post graduation)

\begin{tabular}{|c|c|c|c|}
\hline \multicolumn{2}{|l|}{ Male (A1) } & \multicolumn{2}{|l|}{ Female (A2) } \\
\hline (B1) ${ }^{\text {GRADUATION }}$ & $\begin{array}{l}\text { POST- } \\
\text { GRADUATION } \\
\text { (B2) }\end{array}$ & $\begin{array}{l}\text { GRADUATION } \\
\text { (B1) }\end{array}$ & $\begin{array}{l}\text { POST- } \\
\text { GRADUATION } \\
\text { (B2) }\end{array}$ \\
\hline $\mathrm{N}=13$ & $\mathrm{~N}=13$ & $\mathrm{~N}=13$ & $\mathrm{~N}=12$ \\
\hline
\end{tabular}

A1-Means Male

A2- Means Female

B1- Means Graduation

B2- Means Post-Graduation

\section{Sample:}

51 parents of mentally challenged children in which 26 were male and 25 were female. The study was conducted at the out patient department of S.M.S Psychiatry Centre, Jaipur. The samples were selected by purposive method.

\section{Tools Used:}

The following tools were used in the present study: 


\section{Caregiver burden questionnaire:}

The caregiver burden questionnaire (Kaur and Arora, 2010) is a semi-structured based scale measure the burden associated with rearing such mentally handicapped children usually affects whole of atmosphere of home including routine family life, emotional aspects and financial resource of family. It is 52-items, questions and are rated four point likert scale ranging from 14 , with higher scores representing severe burden. The internal consistency of the scale was calculated as the cronbachs alpha 0.70 or higher was considered as satisfactory and alpha .0 .50 was considered as acceptable. Validity of caregiver burden refers to the presence of problems, difficulty or adverse event that affect the lives of significant others. objective burden used in context with physical burden of care consequent to behavioral changes of mentally ill individual and the social effect of their illness on caregivers daily life. Subjective burden refers to the emotional distress of the caregivers.

\section{Perceived stress scale:}

Perceived stress scale was developed by Cohen, (1983) which consisted of 10 items. Individuals are asked "In the last month, how often have you been upset because of something the happened unexpectedly?" "In the last month, how often have you felt nervous and "stressed"? Each item is rated on a 5 point scale ranging from $0-4$, with higher scores indicating more perceived stress. Reliability: alpha $=.78$, Validity: Correlates in a predicted way with other measure of stress . Score of 13 are considered average and 20 or higher are considered high stress, if it is in this range, it consider learning new reduction techniques as well as increasing exercise to at least three times a week.

\section{Coping Inventory:}

The multi-dimensional coping inventory has been developed by Carver, Scheier, \& Weintraub. (1989) had 60 questions about combining scales into "problem-focused" and "emotion-focused" aggregates "overall" coping index. All questions are scored on a 4-point likert scale ranging from 1(I usually don't do this at all) to 4(I usually do this a lot). Reliability internal consistency was indicated by the Cronbach's alpha value ranging from .45 to .92 , test-retest reliabilities ranging from .46 to .86 , and strong evidence of discriminant and convergent validity, Internal consistencies ranged from 0.51 to 0.99 . Scale was used to assess the different ways in which people respond to stress. This study measures conceptually distinct aspect of problem focused coping, emotional focused coping and association between dispositional and situational coping tendency. The 15 area of coping included in the scale are as follows: (1)Positive reinterpretation and growth (,2) Mental disengagement ,(3).Focus on and venting of emotions ,(4)Use of instrumental social support,(5)Active coping,(6)Denial,(7)Religious coping,(8) Humor , (9)Behavioral disengagement,(10)Restraint,(11) Use of emotional social support,(12) Substance use,(13) Acceptance ,(14)Suppression of competing,(15) Activities Planning . 


\section{Procedure:}

This study was conducted in the department of psychiatry, SMS Medical Hospital, Jaipur. It was $2 \times 2$ factorial designs with purposive sampling. It was conducted on 51 patients who had come to the OPD Services of Psychiatry Department of SMS medical Hospital Jaipur and where primarily diagnosed as suffering from mental retardation according to ICD- 10. Parents of such children fulfilling inclusion and exclusion criteria were selected for the study. Caregiver burden questionnaire, perceived stress scale and coping inventory was used on the parents of the mentally challenged person to assess the burden, stress and coping skills on them. The data thus recorded was analyses statistically.

\section{Statistical Analysis:}

Statistical Analysis was done using the statistical software namely Statistical Package of Social Sciences (SPSS-17.0).

Data Analysis was done by using mean, standard deviation. F test was used to assess the comparison the various variables used in study.

\section{RESULT AND DISCUSSION:}

Table-1shows mean of age of both male and female parents of intellectually disabled children.

\begin{tabular}{|l|l|l|l|l|}
\hline \multirow{3}{*}{ Age } & Gender & N & Mean & SD \\
\cline { 2 - 5 } & Male & 26 & 39.230 & 3.050 \\
\cline { 2 - 5 } & Female & 25 & 36.520 & 3.429 \\
\hline
\end{tabular}

Table 1 shows the mean age of male parents is 39.230 with SD of 3.050 whereas the mean age of female parents is 36.502 with SD of 3.429 .

Table-2.1, ANOVA summary of burden with reference to gender and education $(\mathbf{N}=51)$.

\begin{tabular}{|c|c|c|c|c|c|c|}
\hline Source & $\begin{array}{ll} & \text { Variab } \\
\text { les } & \end{array}$ & S.S & $\mathbf{F}$ & M.S. & Value $^{\text {F- }}$ & Sig \\
\hline $\mathrm{A}$ & Gender & 971.432 & & 971.432 & 37.335 & $0.01 * *$ \\
\hline B & ion & 23.187 & & 23.187 & .891 & NS \\
\hline $\mathrm{AxB}$ & $\begin{array}{l}\text { Gender } \\
\text { * Education }\end{array}$ & 2.245 & & 2.245 & .086 & NS \\
\hline Error & Error & 1222.917 & 7 & 26.020 & & \\
\hline Total & Total & 510618.000 & 1 & & & \\
\hline
\end{tabular}

$* \mathrm{P}<0.05$ level, $* * \mathrm{P}<0.01$ level, NS= Not Significant 
Table-2.2 Difference between mean score of burden with reference to gender and education $(\mathbf{N}=51)$

\begin{tabular}{|c|c|c|c|}
\hline $\begin{array}{l}\text { Independent } \\
\text { Variable }\end{array}$ & $\mathrm{N}$ & Mean (M) & $\begin{array}{l}\text { Difference between } \\
\text { mean }\end{array}$ \\
\hline Male & 26 & 104.115 & 8.712 \\
\hline Female & 25 & 95.400 & \multirow{2}{*}{0.76} \\
\hline Graduation & 26 & 100.00 & \\
\hline Post Graduation & 25 & 99.240 & \\
\hline
\end{tabular}

\section{Burden with reference to gender and education:}

- When F test was applied to check the impact of gender on burden among parents of intellectually disabled children significant $F$ value was found. The $F$ value (Table 2.1) is 37.335 which is statistically significant $(\mathrm{p}<0.01 * *, \mathrm{~F}=37.335)$. Table 2.2 reveals that the mean score of burden of parents of intellectually disabled children are 104.115 and 95.400 respectively and the difference between two is 8.712 which is very unnegligible. Hence the alternative hypothesis was maintained and it was concluded that there was significant impact of gender on burden which indicates male are more prone of having burden than female parents of intellectually disabled children.

- When F test was applied to check the impact of education on burden among parents of intellectually disabled children no significant $F$ value was found. The F value (Table 2.1) is 0.891 which is statistically not significant. Table 2.2 reveals that the mean score of burden of Graduation and Post-Graduation parents of intellectually disabled children are 100.00 and 99.240 respectively and the difference between two is 0.76 which is very negligible. Hence the null hypothesis was maintained and it was concluded that there was no significant impact of education on burden.

- When F test was applied to check the impact of gender and education on burden no significant impact was found. The F value (Table 2.1) is 0.086 which is statistically not significant. Hence the null hypothesis was maintained and it was concluded that there was no significant interaction effect of gender and education on burden which indicates gender and education are not significantly contributing factors of burden. 
Burden, Stress and Coping Strategies of Intellectually Disabled Children

Table-3.1, ANOVA summary of stress with reference to gender and education $(\mathbf{N}=51)$.

\begin{tabular}{|c|c|c|c|c|c|c|}
\hline \multirow{2}{*}{ Source } & Variable & $\begin{array}{l}\text { Type III } \\
\text { Sum of } \\
\text { Squares }\end{array}$ & df & $\begin{array}{l}\text { mean } \\
\text { Square }\end{array}$ & F & Sig. \\
\hline A & Gender & 19.694 & 1 & 19.694 & 15.067 & $0.01^{* *}$ \\
\hline B & Education & 7.789 & 1 & 7.789 & 5.958 & $0.05^{*}$ \\
\hline AxB & $\begin{array}{c}\text { Gender * } \\
\text { Education }\end{array}$ & 2.866 & 1 & 2.866 & 2.192 & NS \\
\hline Error & Error & 61.436 & 47 & 1.307 & & \\
\hline Total & Total & 20611.000 & 51 & & & \\
\hline
\end{tabular}

$* \mathrm{P}<0.05$ level, $* * \mathrm{P}<0.01$ level, NS= Not Significant

Table 3.2, Difference between mean score of stress with reference to gender and education ( $\mathbf{N = 5 1 )}$

\begin{tabular}{|c|c|c|c|}
\hline $\begin{array}{l}\text { Independent } \\
\text { Variable }\end{array}$ & $\mathrm{N}$ & Mean (M) & $\begin{array}{c}\text { Difference } \\
\text { between mean }\end{array}$ \\
\hline Male & 26 & 19.461 & 1.219 \\
\hline Female & 25 & 20.680 & \multirow{2}{*}{0.748} \\
\hline Graduation & 26 & 19.692 & \\
\hline Post Graduation & 25 & 20.440 & \\
\hline
\end{tabular}

\section{Stress with reference to gender and education:}

- When F test was applied to check the impact of gender on stress among parents of intellectually disabled children, significant $\mathrm{F}$ value was found $(\mathrm{P}<0.01 * *, \mathrm{~F}=15.067)$. The F value (Table 3.1) is 15.067 which is statistically significant. Table 3.2 reveals that the mean score of stress of parents of intellectually disabled children are 19.461 and 20.680 respectively and the difference between two is 1.219 which is very unnegligible. Hence the alternative hypothesis was maintained and it was concluded that there was significant impact of gender on stress which indicates female are more prone of having stress than male parents of intellectually disabled children.

- When F test was applied to check the impact of education on stress significant $F$ value was found. The F value (Table 3.1) is 5.958 which is statistically significant $\left(\mathrm{P}<0.05^{*}\right)$. Table 3.2 reveals that the mean score of stress of Graduation and Post-Graduation parents of intellectually disabled children are 19.692 and 20.440 respectively and the difference between two is 0.748 which is unnegligible. Hence the alternative hypothesis was maintained and it was concluded that there was significant impact of education on stress indicating Post-Graduate parents are more stress than Graduate parents.

- When F test was applied to check the impact of gender and education on stress no 
significant impact was found. The F value (Table 3.1) is 2.192 which is statistically not significant. Hence the null hypothesis was maintained and it was concluded that there was no significant interaction effect of gender and education on stress which indicates gender and education are not significantly influence factor of stress.

Table 4.1 ANOVA summary of coping with reference to gender and education $(\mathbf{N}=51)$.

\begin{tabular}{|c|l|l|l|l|l|l|}
\hline Source & & \multicolumn{2}{|c|}{ Type } & & & \\
& Variable & $\begin{array}{l}\text { III Sum of } \\
\text { Squares }\end{array}$ & df & $\begin{array}{l}\text { Mean } \\
\text { Square }\end{array}$ & F & Sig. \\
\hline A & Gender & 924.250 & 1 & 924.250 & 20.623 & $0.01 * *$ \\
\hline B & Education & 4.526 & 1 & 4.526 & .101 & NS \\
\hline AxB & $\begin{array}{l}\text { Gender * } \\
\text { Education }\end{array}$ & 80.821 & 1 & 80.821 & 1.803 & NS \\
\hline Error & Error & 2106.385 & 47 & 44.817 & & \\
\hline Total & Total & 718428.000 & 51 & & & \\
\hline
\end{tabular}

$* \mathrm{P}<0.05$ level, $* * \mathrm{P}<0.01$ level, NS= Not Significant

Table 4.2, Difference between mean score of coping with reference to gender and education $(\mathbf{N}=51)$

\begin{tabular}{|c|c|c|c|}
\hline $\begin{array}{c}\text { Independent } \\
\text { Variable }\end{array}$ & $\mathrm{N}$ & Mean (M) & $\begin{array}{c}\text { Difference } \\
\text { between mean }\end{array}$ \\
\hline Male & 26 & 122.58 & 8.46 \\
\hline Female & 25 & 114.12 & \\
\hline Graduation & 26 & 118.62 & 0.38 \\
\hline $\begin{array}{c}\text { Post } \\
\text { Graduation }\end{array}$ & 25 & 118.24 & \\
\hline
\end{tabular}

\section{Coping with reference to gender and education:}

- When F test was applied to check the impact of gender on coping among parents of intellectually disabled children, significant $\mathrm{F}$ value was found $(\mathrm{P}<0.01, \mathrm{~F}=20.623)$ The F value (Table 4.1) is 20.623 which is statistically significant. Table 4.2 reveals that the mean score of coping of parents of intellectually disabled children are 122.58 and 114.12 respectively and the difference between two is 8.46 which is very unnegligible. Hence the alternative hypothesis was maintained and it was concluded that there was significant impact of gender on coping which indicates parents male are more good coping skills than female parents of intellectually disabled children.

- When F test was applied to check the impact of education on coping no significant $\mathrm{F}$ value was found. The $\mathrm{F}$ value (Table 4.1 ) is 0.101 which is statistically not 
significant. Table 4.2 reveals that the mean score of coping of Graduation and PostGraduation parents of intellectually disabled children are 118.62 and 118.24 respectively and the difference between two is 0.38 which is negligible. Hence the null hypothesis was maintained and it was concluded that there was no significant impact of education on coping.

- When F test was applied to check the impact of gender and education on coping no significant impact was found. The F value (Table 4.1) is 1.803 which is statistically not significant. Hence the null hypothesis was maintained and it was concluded gender and education are not significantly influencing factors of coping.

\section{DISCUSSION:}

The finding of the present study found significant impact of gender on burden which indicates male parents are more prone of having burden than female parents of intellectually disabled children. This may be because child care activities that promote children's social-emotional development were related to fathers' societal generativity or capability. This finding is supported by Keering et al. (2000) which explored fatherhood from an Eriksonian developmental perspective and proposed parenting as a key stimulus for fathers' societal generativity. Their findings indicated that child care was related to fathers' societal generativity but not to mothers. It also emphasize particular child care activities that promoted children's social-emotional development were related to fathers' societal generativity, whereas activities that promoted children's academic-intellectual development were related to mothers' societal generativity.

The result of this study found gender and education are not significantly contributing factors of burden. This finding is supported by the study of Wilson (2003) which found the equal rights of education of both male and female helps to remove burden in family.

The present study revealed significant impact of gender on stress which indicates female are more stress than male parents of intellectually disabled children. This finding is supported by (Peshawaria \& Ganguli , 1995) Parents having a mentally retarded child experience a variety of 'psychological stress' related to the child's disability. Parents especially mothers need every help and encouragement possible in their difficult task, which indeed easier for them while the child is still a baby. An anxious love, on the part of the mother, may do much to exacerbate the defective's disability. (North Star High School, 1974).

The result of the study found significant impact of education on stress indicating Post-Graduate parents are having more stress than Graduate parents. This may be because they require to face more competition with colleagues in office and on the other side family are expected high from them. Supportively, Suldo et.al., (2009) parents of high education have been affected by heavy focus on acceptance into employment, to cope with a strenuous workload, high pressure family environment \& internalization of high expectation from home and fellows. 
Similarly, Crona et.al. ,2009) found highly educated people are expected to handle many complicated stressor and also gave many responsibilities in office and home.

The study found no significant interaction effect of gender and education on stress indicating gender and education are not significantly influence on stress. The reason may be parents who are greatly satisfied with their jobs which in turn get low stress. Likewise, Barnett et al.(1995)found that positive experiences on the job \& role of partner or family member support leads to low distress. (Barnett et al.1993; Barnett, Brennan \& Marshal,1994).

The study found significant impact of gender on coping which indicates male are more good coping skills than female parents of intellectually disabled children. The reason may be males are busy in their responsibilities, official work and earning money as they are the only source of income for whole family. Supportively, Dubowitz and Bender (2007) found male as a source of income and handling their responsibilities with overall satisfaction which may lead to less emotional distress, social competence, less expression of negative emotionality such as fear \& guilt and capacity for relatedness with other indicates the good mental health. Male approach the problems by using strategies which helps them to give support to resolve the conflict and solving it effectively in the best possible manner.

Likewise, Spillman and Pezzin (2000) found most caregivers are women who handle timeconsuming and difficult tasks like personal care. But at least 40 percent of caregivers are men, a growing trend demonstrated by a 50 percent increase in male caregivers between 1984 and 1994. These male caregivers are becoming more involved in complex tasks like managing finances and arranging care, as well as direct assistance with more personal care.

The study identify no significant interaction effect of gender and education on coping which means gender and education are not significant factor of coping. The reason may be because coping depends on good mental health and the skills which the person has. This is supported by the Hinton and Earnest(2010) found that a number of women is use avoidance strategies who were lower level of self-esteem and life-satisfaction and those women who were high level of anxiety also indicates poor coping to those who has lower self-esteem ,life-satisfaction and anxiety.

\section{CONCLUSION:}

The Result of this study showed there is significant difference between male and female on burden indicating higher burden on male parents. There is significant difference of stress between male and female parents indicating higher perceived stress on female parents. There is significant difference between male and female parents on coping indicating male parents are having good coping skills in comparison to female parents. The study concluded that male parents are getting more burden, female parents gets more stress and when concerned about coping male parents are good in coping strategies than female parents. 


\section{LIMITATION \& FUTURE DIRECTIONS}

- Large population having equal representation of all categories of mental retardation should being included.

- Techniques used for better coping should be assessed so that other parents can also be benefitted.

\section{REFERENCES:}

American association of Mental deficiency (1983). Classification in mental retardation. Retrieved from: https://law.resource.org/pub/us/cfr/ibr/001/aamd.classification.1973.pdf on 30/4/2015.

Brannan, A.M., Heflinger, C. A., \& Bickman, L. (1993). The caregiver strain questionnaire: Measuring the impact on the family of living with a child with serious emotional disturbance. Journal of Emotional and Behavioral Disorders, 5(4), 212-222.

Barnett, T., DeLuca, D. A., \& Allen, R. W. (1995) Religion and children with disabilities. Journal of Religion and Health . 34, 301-312.

Bennett, T., DeLuca, D. A., \& Allen, R. W. (1994) Religion and children with disabilities. Journal of Religion and Health . 34, 301-312.

Carver, C. S., Scheier, M. F., \& Weintraub, J. K. (1989). Assessing coping strategies: A theoretically based approach. Journal of Personality and Social Psychology, 56, 267283.

Cohen, S. , Kamarck, T., \& Mermelstein, R. (1983). A global measure of perceived stress. Jounal of Health and Social Behavior, 24, 385-396.

Crona, B., Wutich, A., Brewis, A., \& Gartin, M. (2009). Perceptions of climate change: Linking local and global perceptions through a cultural knowledge approach. Retrieved from www.urban-sustainability ren.org/.../crona_et_al_2013_climate_change...on 2/5/2015.

Dubowitz, H., \& Poole, G. (2012). Child Neglect: An Overview. Encyclopedia on Early Childhood Development. Retrieved from ww.childencyclopedia.com/Pages/PDF/Dubowitz-PoolANGxp1.pdf on 2/5/2015.

Hinton,R. \& Earnest, J.(2010). Stressor, Coping and Social Support among women in Papua New Guinea. Quality health resource,20(2),224-38

Kaur, R., \& Arora, H. (2010). Attitudes of Family Members Towards Mentally Handicapped Children and Family Burden. Delhi Psychiatric Journal, 13 (1), 70-74.

ICMR(1983). In T. Madhavan; M.Kalyan;S.Naidu; R.Peshwaria\& J. Narayan(contributors). Mental Retardation: A manual for psychologist. National Institute for the Mentally Handicapped (Under the Ministry of Social Justice \& Enpowerment,Government of India),Manovikas Nagar,P.O., Secunderabad-500009.Andhra Pradesh. India.

Jablensky,A., Schwartz,R.\& Tomov,T.(1980). WHO Collaborative study on impairement \& disabilities in schizophrenic patient. Indian Journal of Psychiatry,13(1),47-53.

Rajdeep Kaur,R., \& Harish Arora, H. (2010). Attitudes of Family Members Towards Mentally Handicapped Children and Family Burden.Delhi Psychiatric Journal, 13(1), 70-74.

Keering, M.C., \& Kenneth, I. .(2000). Gender and Generativity Issues in Parenting: Do Fathers Benefit More Than Mothers From Involvement in Child Care Activities. Sex Roles , 43 , 193-214 
North Star High School (1974). Yearbook: Boswell, Pennsylvania. Retrieved from http://www.amazon.com/Reprint-1974-Yearbook-BoswellPennsylvania/dp/B0041FHQ98 on 2/5/2015.

Peshwaria R \& Ganguli R, (1995) Families having person with mental retardation Project Report, NIMH, Secunderabad- 500009.

Singh , T.K. Indla, V., \& Reddy,R. (2008). Impact of disability of mentally retarded persons on their parents. Indian Journal of Psychological Medicine, 30 (2), 98-104.

Spillman, B.C, \&Pezzin L.E. (2000). Potential and active family caregivers: Changing networks and the "sandwich generation.Milbank Mem Fund ;78:347-74.

Suldo, S. M., Shaunessy, E., \& Hardesty, R. (2009). Relationships Among Stress, Coping, And Mental Health In High-Achieving High School Students. Psychology in the Schools, 45(4), 273-290.

Wilson (2003) .Human Rights. Promoting gender equality in and through education. Disability \& Society, 26(4),83-94.

WHO, (1980): International classification of impairments, disabilities and handicaps.Geneva,World health Organisation. 